\title{
Invited review: Mid-infrared spectroscopy as phenotyping tool for milk traits ${ }^{1}$
}

\author{
M. De Marchi, ${ }^{2}$ V. Toffanin, M. Cassandro, and M. Penasa \\ Department of Agronomy, Food, Natural Resources, Animals and Environment (DAFNAE), University of Padova, Viale dell'Università 16, \\ 35020 Legnaro (PD), Italy
}

\begin{abstract}
Interest in methods that routinely and accurately measure and predict animal characteristics is growing in importance, both for quality characterization of livestock products and for genetic purposes. Mid-infrared spectroscopy (MIRS) is a rapid and cost-effective tool for recording phenotypes at the population level. Midinfrared spectroscopy is based on crossing matter by electromagnetic radiation and on the subsequent measure of energy absorption, and it is commonly used to determine traditional milk quality traits in official milk laboratories. The aim of this review was to focus on the use of MIRS to predict new milk phenotypes of economic relevance such as fatty acid and protein composition, coagulation properties, acidity, mineral composition, ketone bodies, body energy status, and methane emissions. Analysis of the literature demonstrated the feasibility of MIRS to predict these traits, with different accuracies and with margins of improvement of prediction equations. In general, the reviewed papers underlined the influence of data variability, reference method, and unit of measurement on the development of robust models. A crucial point in favor of the application of MIRS is to stimulate the exchange of data among countries to develop equations that take into account the biological variability of the studied traits under different conditions. Due to the large variability of reference methods used for MIRS calibration, it is essential to standardize the methods used within and across countries.
\end{abstract}

Key words: mid-infrared spectroscopy, phenotyping, quality trait, dairy cattle

Received March 13, 2013.

Accepted November 8, 2013.

${ }^{1}$ M. De Marchi designed and wrote the first draft of the manuscript and V. Toffanin, M. Penasa, and M. Cassandro were involved in drafting the paper. All authors contributed to the discussion of the review.

${ }^{2}$ Corresponding author: massimo.demarchi@unipd.it

\section{INTRODUCTION}

In the genomic era, phenomics is becoming a compulsory research field. This new science is concerned with the acquisition of phenotypic data on a large scale (Houle et al., 2010) and the phenotype can be described as the outcome of the interacting development between the genotype of an individual and its specific environment throughout life (Bowman, 1974). The interest in methods that routinely and accurately measure and predict animal characteristics (i.e., phenotypes) is rapidly growing. Accurate phenotypes and efficient phenotyping tools are the key ingredients, especially for genomic selection of livestock animals, which is expected to increase the genetic gain of the selected traits (Pryce et al., 2010; Lillehammer et al., 2011; Mc Hugh et al., 2011).

Furthermore, in recent years, consumers and the dairy industry have shifted the concept of quality in relation to market requirements: for example, milk coagulation traits have been studied to improve cheese production and FA composition to enrich the nutritional value of milk for human health. Breeding goals have followed these changes: if phenotypes are accurately and cheaply measured at the population level and integrated in the national milk recording systems, it may be possible to enhance the traits using genetic or genomic tools.

The need for fast, cheap, and high-throughput methods of chemical analysis has also led to the application of infrared spectroscopy in both the livestock and food sectors. The spectroscopic technique is based on the study of the interaction between matter and electromagnetic waves. Electromagnetic radiation comprises different regions according to the following wavelengths: the $\mathrm{x}$ ray region $(0.5-10 \mathrm{~nm})$, UV region $(10-350 \mathrm{~nm})$, visible region (350-800 nm), near-infrared region (800-2,500 $\mathrm{nm})$, mid-infrared region $(2,500-25,000 \mathrm{~nm})$, microwave region $(100 \mu \mathrm{m}-1 \mathrm{~cm})$, and radio frequency region (1 $\mathrm{cm}-1 \mathrm{~m})$.

One of the most important historical events for the spectroscopic technique was the development of the Fourier transform in the 1700s; in later years, this mathematical transform was improved with the use of the interferometer. In 1969, Digilab Inc. (Marlborough, MA) put the first Fourier-transform infrared spectro- 
photometer with a dedicated minicomputer on the market, which was later refined in 1983 by the same company (Spectra-Tech Inc., Oak Ridge, TN). From the 1980s, Fourier-transform infrared spectrophotometers were combined with personal computers and this method of analysis became widely used due to its versatility and cost effectiveness. Since then, many studies have investigated the relationships between spectra wavelengths and several quality traits through the explanation of chemical bond variations.

Mid-infrared spectroscopy (MIRS) has been evaluated as a potential tool to collect data at the population level for phenotypic and genetic purposes, and it is becoming one of the major topics in dairy science. In the mid-infrared region, when matter is crossed by electromagnetic radiation, the bonds of the molecules make movements (e.g., vibration and rotation), which involve a more or less marked absorption of the provided energy. On the basis of supplied energy and the amount absorbed by the irradiated sample, and using spectra mathematical pretreatments, it is possible to determine the sample's chemical composition and correlated compounds (Figure 1 ).

The present review summarizes papers that have investigated the use of MIRS to predict milk quality traits. Furthermore, studies that adopted this technique to predict nutritional, technological, and other traits of economic relevance are also reviewed.

\section{PHENOTYPING OF MILK BY MIRS}

Studies that aimed at investigating the effectiveness of MIRS to predict phenotypes for dairy industry applications or for genetic purposes have markedly increased over the years. Figure 2 depicts the trend in the number of papers published from 2001 to 2013 on the application of MIRS to milk, highlighting a growing interest for the topic, particularly in the last $3 \mathrm{yr}$. This is confirmed also by large international research projects that aimed at predicting new traits in the dairy industry (e.g., OptiMIR, 2012; RobustMilk, 2012). In animal science, phenomics is mainly related to the study of phenotypes of an individual. A phenotype should be routinely, cheaply, and easily measurable, should show good to optimal accuracy of prediction, depending on its use, and should exhibit genetic variation or, if it is a predictor of the real phenotype of interest, high genetic correlation with the trait of interest (Berry et al., 2012).

Currently, MIRS is used to determine quality traits in bulk and individual milk samples. In particular, most countries use MIRS in official milk-recording schemes to predict protein, casein, fat, lactose, and urea contents. Besides these traditional traits, MIRS
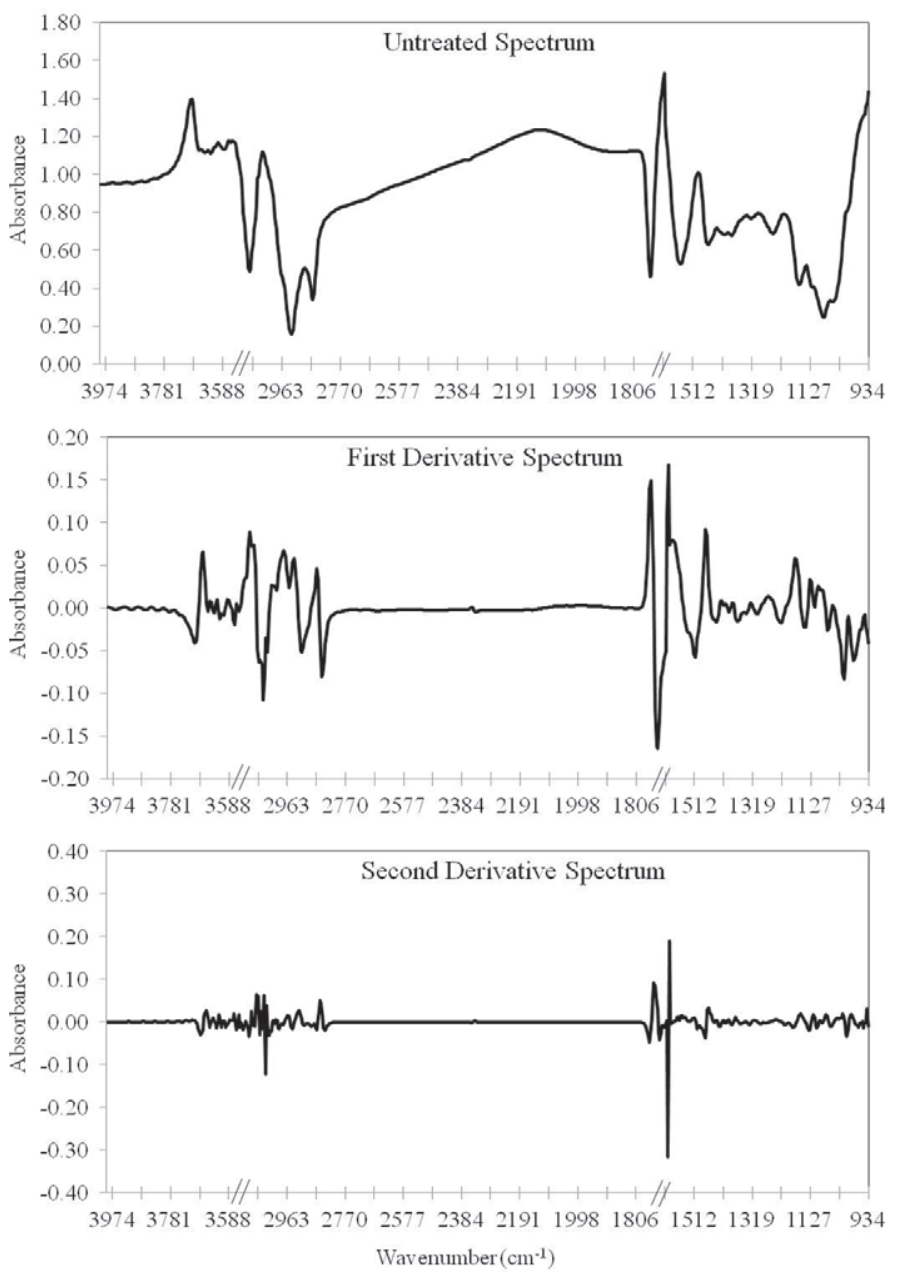

Figure 1. Examples of untreated, first-derivative, and second-derivative spectra.

has been used to predict other milk characteristics: FA composition (Soyeurt et al., 2006, 2008, 2011; Rutten et al., 2009; De Marchi et al., 2011; Ferrand et al., 2011; Maurice-Van Eijndhoven et al., 2013), milk protein composition (Luginbühl, 2002; Sørensen et al., 2003; Etzion et al., 2004; De Marchi et al., 2009a; Bonfatti et al., 2011; Rutten et al., 2011), milk coagulation properties (MCP; Dal Zotto et al., 2008; De Marchi et al., 2009b, 2013), milk acidity (De Marchi et al., 2009b), mineral composition (Soyeurt et al., 2009), melamine content (Balabin and Smirnov, 2011), ketone bodies (Heuer et al., 2001; de Roos et al., 2007; van Knegsel et al., 2010; van der Drift et al., 2012), body energy status (McParland et al., 2011), and methane emissions (Dehareng et al., 2012).

In addition, several laboratories involved in routine milk-recording systems have been storing spectral data to predict a posteriori several phenotypes; this approach is very interesting for genetic purposes. 


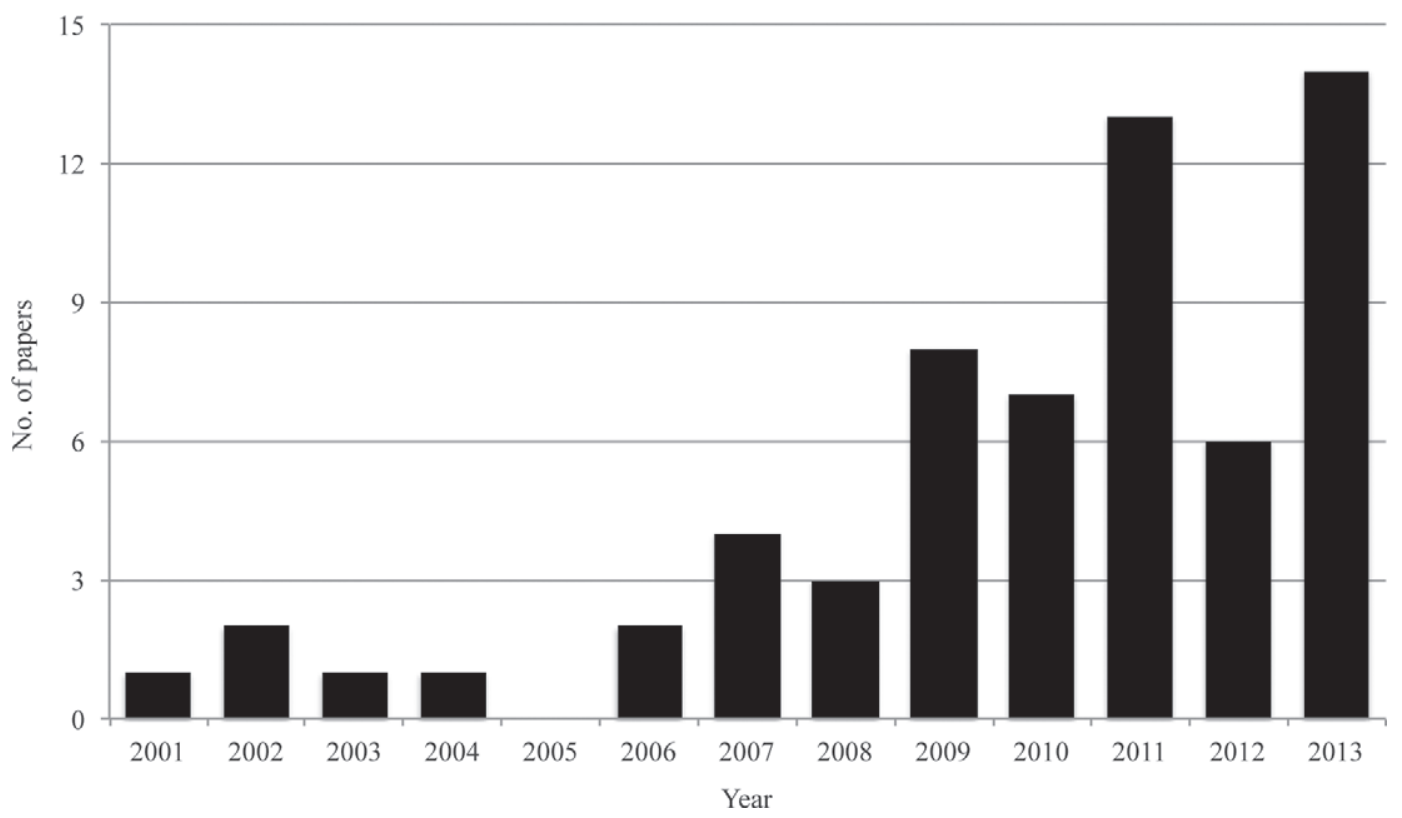

Figure 2. Published papers (retrieved from ISI Web of Science; http://thomsonreuters.com/web-of-science/) on mid-infrared spectroscopy (MIRS) and milk. For 2013, papers published up to October are reported.

\section{SPECTRA PRETREATMENTS}

Pretreatments of MIRS spectral data are very common and often of great importance to obtain robust prediction models (Rinnan et al., 2009). The main goal of using statistical procedures for preprocessing spectral data is to improve the linear relationship between the spectra and the gold reference. As reported by Rinnan et al. (2009), several phenomena can cause a deviation from the aforementioned linear relation: scatter from particulates, molecular interactions, and changes in sample size. The most common preprocessing techniques for MIRS data are those that directly use available reference values, such as scatter correction and derivation methods. The scatter correction methods include multiplicative scatter correction, standard normal variate, and normalization. Regarding the derivation methods, the most commonly used is the Savitzky-Golay derivative.

Briefly, multiplicative scatter correction aims at removing nonlinearities in the spectral data caused by scatter from particulates in the samples (Martens et al., 1983) and this is very similar in result to standard normal variate (Rinnan et al., 2009). Figure 1 depicts the variation of spectra peaks moving from untreated data to first and second derivatives. The main benefits of the use of derivative spectra pretreatments are to improve the resolution of the spectra (first derivative) and to give a negative peak for each band and shoulder (second derivative); the most common derivatives used for these purposes were developed by Savitzky and
Golay (1964). Generally, the sharp bands are enhanced at the expense of broad ones (Figure 1) and this may allow for the selection of suitable peaks (Stuart, 2004).

Despite mathematical pretreatments being widely used in the building of MIRS prediction models, the authors usually report only the best model with the related mathematical method and, hence, the comparison among different mathematical pretreatments is not possible. Only Soyeurt et al. (2011) and De Marchi et al. (2011) investigated the variation in the accuracy of MIRS prediction models for FA composition using different mathematical pretreatments; they found quite similar results, showing better accuracies using derivative pretreatment than untreated spectral data. In a similar manner, De Marchi et al. (2009b) investigated the effect of different spectra pretreatments for the prediction of MCP and they found better accuracies using untreated spectral data; this has been recently confirmed by De Marchi et al. (2013).

\section{FITTING STATISTICS OF CHEMOMETRIC ANALYSIS}

Partial least squares (PLS) modeling is a powerful multivariate statistical tool that has been widely applied to the quantitative spectral analyses of MIRS and near-infrared data (De Marchi et al., 2012; Riovanto et al., 2012). Because several software packages using the PLS technique are available, it is important to understand how chemometric results can be compared. Several statistic parameters exist that can be used to 
assess the goodness of PLS models both in calibration and validation (Næs et al., 2002). Reference statistics are the validation ones, which are calculated after the development of the calibration equation; they are essential in determining the ability of calibration models to predict unknown values. The most important parameters are the coefficient of determination and standard error of calibration and validation, the relative ability of prediction, ratio to performance deviation (RPD), range error ratio (RER), relative prediction error (RPE), and concordance correlation coefficient (CCC; Williams and Norris, 2001; Williams, 2003).

The coefficient of determination in calibration $\left(\mathrm{R}_{\mathrm{C}}^{2}\right)$ and validation $(\mathbf{1}-\mathbf{V R}$, where $\mathrm{VR}=$ variance ratio $)$ are calculated as the square of the correlation coefficient between the reference values and their corresponding predicted values obtained using calibration and validation sets. The coefficient of determination in validation depends on the validation technique: (1) use of an external data respect to calibration set or (2) cross-validation on calibration data according to Stone (1974).

The standard error is essential to determine the ability of the calibration equation to predict unknown values as good calibration equations have small standard errors. Three types of standard error exist: (1) standard error of calibration, which is obtained by testing the calibration equation directly on calibration data and it is usually a highly over-optimistic estimate of the prediction ability; (2) standard error of external validation (SEP), which is based on splitting the data set into 2 subsets, one for calibration and the other for validation; and (3) standard error of cross-validation, based on the previously described cross-validation technique (Williams and Norris, 2001; Sivakesava and Irudayaraj, 2002; Williams, 2003). During the development of calibration models, the SEP is used for determining the optical number of components (\#L); usually the SEP is large when \#L is low and decreases as \#L increases. Partial least squares models allow the selection of appropriate \#L to model as much of the complexity of the system without overfitting the data (Haaland and Thomas, 1988; Næs et al., 2002). The relative ability of prediction is defined as a variant of the correlation coefficient and it aims at correcting the standard correlation for the variance of error in the calibration set (Hildrum et al., 1983).

The RPD, RER, RPE, and CCC provide information on the practical utility of prediction models and allow the comparison of models among different studies. The RER is calculated by dividing the range of a given parameter by the standard error in validation; models with RER values lower than 3 have little practical util- ity, values between 3 and 10 have limited to good practical utility, and values greater than 10 have high utility (Williams, 1987). The RPD is calculated by dividing the standard deviation and standard error in validation of a given trait; values of RPD greater than 10 are considered equivalent to reference methods, whereas values larger than 2 are considered adequate for analytical purposes (Karoui et al., 2006). As reported by Fuentes-Pila et al. (1996) and Lopez-Villalobos et al. (2009), RPE values lower than $10 \%$ indicate satisfactory predictions, from 10 to $20 \%$ indicate relatively acceptable predictions, and larger than $20 \%$ indicate poor predictions. Regarding the CCC, values from 0.81 to 1.00 indicate perfect prediction ability, from 0.61 to 0.80 substantial prediction ability, from 0.41 to 0.60 moderate prediction ability, and from 0.21 to 0.40 fair prediction ability (Lin, 1989; Lopez-Villalobos et al., 2009).

\section{FA COMPOSITION OF MILK}

Milk fat and FA composition are important quality traits, as they influence the sensory attributes, technological properties, and nutritional value of milk, and are related to human health. Bovine milk contains 70\% SFA, 25\% MUFA, and 5\% PUFA (Grummer, 1991). The daily intake of SFA from dairy products has great relevance for the consumer (Chilliard et al., 2001) and the effects of variation of SFA, MUFA, and PUFA content in the diet on human health have been widely described (Mensink and Katan, 1992; German et al., 2009), along with the role of conjugated linoleic acid. Furthermore, FA composition influences the technological traits of butter, such as the spreadability (MacGibbon and McLennan, 1987). Therefore, feeding and breeding strategies to favorably alter the FA composition of bovine milk could be very beneficial. Recently, Lopez-Villalobos (2012) reviewed the genetic basis of FA and reported moderate heritability for FA, suggesting that the improvement of these traits through selection is feasible.

In recent years, several authors have attempted to predict FA and groups of FA (GFA) using MIRS (Table 1). Studies were conducted using (1) different numbers of samples, (2) different spectra pretreatments, (3) different reference methods, and (4) different units of measures of FA and GFA. The number of milk samples used to build prediction models for FA and GFA ranged from 49 to 3,622 (Table 1) and influenced the PLS analysis, in particular the validation procedures (crossvalidation vs. independent validation). The cross-validation procedure has been used for a limited number of samples, as reported by Soyeurt et al. $(2006,2008)$ and De Marchi et al. (2011); however, independent 
validation is more commonly used (Rutten et al., 2009; Ferrand et al., 2011; Soyeurt et al., 2011; Maurice-Van Eijndhoven et al., 2013). These studies were conducted on individual milk samples, mostly collected on different cow breeds; only De Marchi et al. (2011) used milk samples from a single breed and reported difficulties in developing MIRS prediction models for several FA due to the limited range of variation of these compounds.

Concerning the methods of spectra preprocessing, most studies have been conducted on untreated spectral data or, to a less extent, using first-derivative spectra pretreatment. Soyeurt et al. (2011) and De Marchi et al. (2011) investigated the variation in the accuracy of MIRS prediction models using different mathematical pretreatments; they reported quite similar results, with better accuracies of prediction models using derivative pretreatment with respect to untreated spectral data.

The reference method for the assessment of FA composition is based on 2 major phases: fat extraction and gas chromatography analysis. The extraction procedure has been conducted using 3 methods and gas chromatography using very different columns and analytical conditions (Table 1). Because calibration models were carried out using different spectral data, statistical procedures, and gold standard methods, the effect of reference method on the accuracy of MIRS prediction models is not determinable.

Table 1. Number of calibration samples, number of breeds, reference method, and validation procedures used in the studies aimed at developing mid-infrared spectroscopy (MIRS) prediction models for milk FA

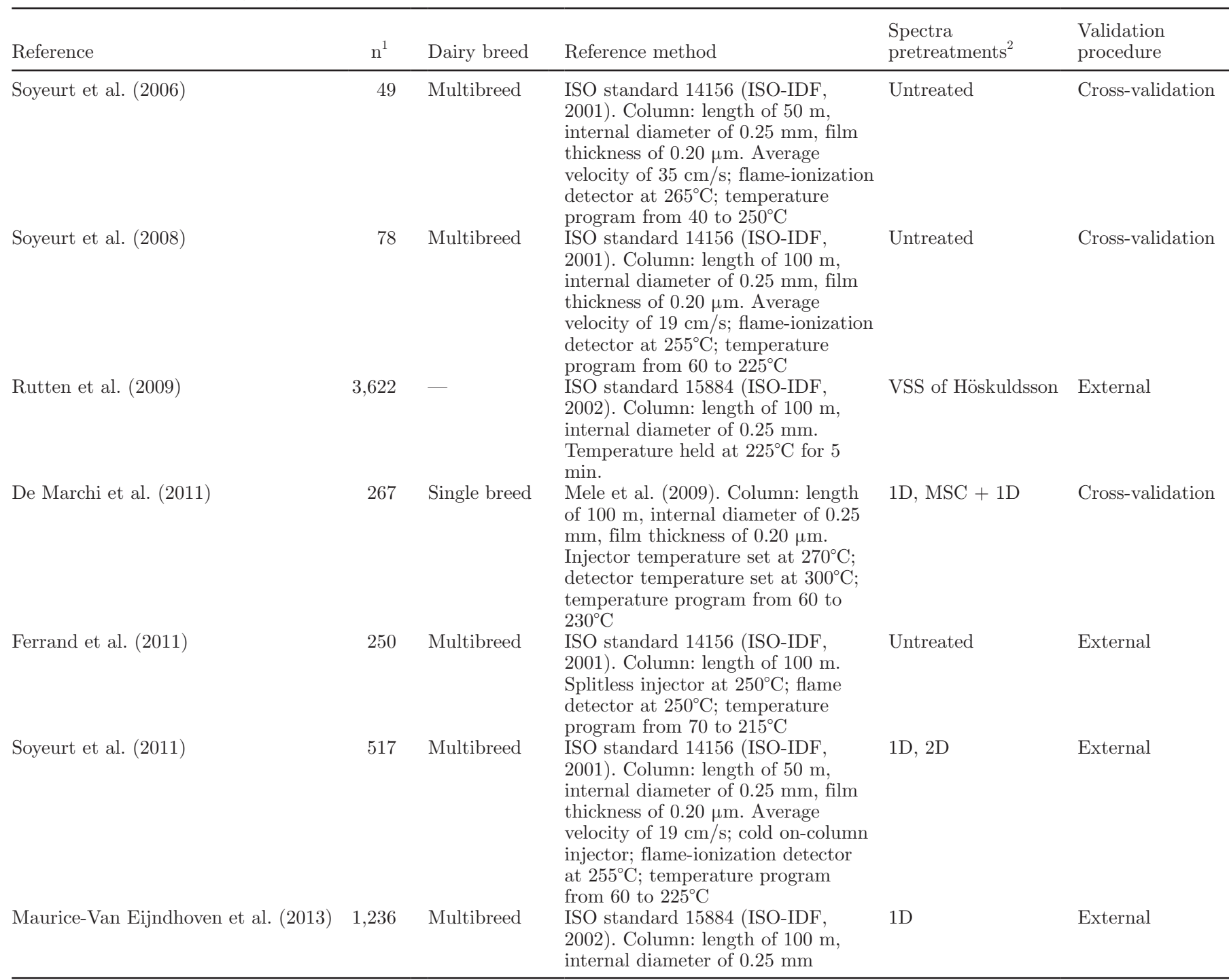

${ }^{1}$ Number of samples used for calibration models.

${ }^{2} \mathrm{VSS}=$ variable selection strategy $; 1 \mathrm{D}=$ first derivative; $2 \mathrm{D}=$ second derivative; $\mathrm{MSC}=$ multiplicative scatter correction. 
The unit of measure of FA and GFA is another crucial point in the development of accurate MIRS prediction models. Most studies expressed FA and GFA as the quantity per unit of milk, and only Soyeurt et al. (2006) and Rutten et al. (2009) predicted FA composition for FA expressed as quantity of total fat (Tables 2,3 , and 4). Both studies reported that, on average, the accuracy of MIRS prediction models were better when FA and GFA were expressed as quantity per unit of milk. This was also confirmed by De Marchi et al. (2011), who reported that the prediction of FA using MIRS is the combined effect of predicting fat content and fat composition. The prediction of FA is performed on milk samples, whereas reference methods for FA determination are performed on fat extracted from milk, which means that their relationship is affected also by the variation in fat percentage. Therefore, we will hereafter focus on prediction models developed on FA and GFA expressed per unit of milk. The difficulty of MIRS to predict FA when they are expressed on a fat basis represents a limitation in the application of this technique; in fact, this information is essential when the interest is to change only the fat composition (e.g., through selection). This situation represents a critical point also in the case of protein, as described in the following section and as previously reported by Rutten et al. (2011).

The accuracies of prediction models for SFA from different studies are reported in Table 2. Overall, prediction models for C4:0, C6:0, C8:0, C10:0, C12:0, C14:0, and C16:0 showed high accuracy. Stearic acid (C18:0) had quite good predictability by MIRS, with 1 - VR from 0.09 to 0.88. Only De Marchi et al. (2011) have attempted to predict $\mathrm{C} 20: 0$, but with unsatisfactory results $(1-$ VR of 0.29$)$. Prediction models achieved better results for SFA than unsaturated FA. Mid-infrared spectroscopy showed quite good potential to predict cis-9 C14:1 (1 - VR from 0.07 to 0.53), cis-9 C16:1 (1 - VR from 0.28 to 0.65$)$, trans-11 C18:1 (1 - VR from 0.31 to 0.63 ), and cis-9,cis-12,cis-15 C18:3 (1 VR from 0.14 to 0.60 ; Table 3$)$. Very good results were obtained for C18:1 (1 - VR from 0.53 to 0.91) and cis-9 C18:1 (1 - VR from 0.53 to 0.95$)$. Only 3 studies have attempted to predict linolenic acid (cis-9,cis12,cis-15 C18:3), obtaining low to medium accuracy of prediction. Mid-infrared spectroscopy showed medium potential to predict the 2 isomers of conjugated linoleic acid (cis-9,trans-11 C18:2 and cis-9,cis-12 C18:2; Table 3 ), with $1-$ VR from 0.07 to 0.71 and a wide variability of accuracy of prediction models.

Regarding the GFA, MIRS prediction models highlighted very good accuracies; SFA and MUFA achieved 1 - VR up to 0.85 (Soyeurt et al., 2006, 2011; Ferrand et al., 2011; Maurice-Van Eijndhoven et al., 2013), with the exception of De Marchi et al. (2011), who reported 1 - VR of 0.52 and 0.55 for SFA and MUFA, respectively. Polyunsaturated FA were not very well predicted by MIRS ( 1 - VR from 0.10 to 0.41 ); only Soyeurt et al. (2011) found high 1 - VR for PUFA (0.81). Regarding the short-chain, medium-chain, and long-chain FA, results were often very satisfactory, with 1 - VR up to 0.90 (Table 4). The notably better results obtained by Soyeurt et al. (2011) could be related to (1) huge biological variability of calibration data (milk samples were collected from different breeds, countries, and production systems) and (2) statistical procedures that used several different mathematical pretreatments of spectral data.

The accuracies of MIRS prediction models for major FA were better than for minor FA; the relationship between FA content in milk and accuracy of prediction was discussed by Soyeurt et al. (2006), Rutten et al. (2009), De Marchi et al. (2011), and Maurice-Van Eijndhoven et al. (2013). In particular, Rutten et al. (2009) and De Marchi et al. (2011) reported a strong relationship of FA concentration with $1-\mathrm{VR}$ and the RPD (which is the ratio of the standard deviation to standard error of validation of the trait; Williams, 2001).

The accuracy of prediction models can be affected by the characteristics of the data set; in particular, breed of cows, stage of lactation, and season of sampling are the main aspects to take into consideration during sample collection (Rutten et al., 2009; MauriceVan Eijndhoven et al., 2013). Moreover, as reported by Soyeurt et al. (2011), the variation of MIRS prediction accuracy is not only related to FA concentration but also to spectra variability, the maximization of which is an effective way to improve the accuracy of prediction.

In general, MIRS has widely demonstrated its potential to predict FA and GFA. Nevertheless, milk composition of calibration data set plays a fundamental role in building good prediction models. The development of MIRS prediction equations using milk selected from different breeds, countries, and seasons, and the use of the same reference method seem the best way to improve the accuracy and robustness of MIRS calibrations.

\section{MILK COAGULATION PROPERTIES AND ACIDITY}

The volume of milk destined for cheese manufacturing is growing worldwide and, thus, the characteristics of milk related to cheese making, and cheese yield and quality are relevant for the dairy industry. Milk coagulation properties, acidity, and protein composition are important actors in cheese production (Aleandri et al., 1989; Wedholm et al., 2006; De Marchi et al., 2009a; Pretto et al., 2013). 
Table 2. Unit of measurement, coefficient of determination, and prediction error (in parentheses) of validation procedures for mid-infrared spectroscopy (MIRS) prediction models of selected SFA

\begin{tabular}{|c|c|c|c|c|c|c|c|c|c|c|}
\hline \multirow[b]{2}{*}{ Reference } & \multirow[b]{2}{*}{ Unit } & \multicolumn{9}{|c|}{ SFA } \\
\hline & & $\mathrm{C} 4: 0$ & C6:0 & $\mathrm{C} 8: 0$ & C10:0 & C12:0 & C14:0 & C16:0 & C18:0 & C20:0 \\
\hline \multirow[t]{2}{*}{ Soyeurt et al. (2006) } & $\mathrm{g} / \mathrm{dL}$ of milk & $0.51(0.08)$ & $0.52(0.04)$ & $0.59(0.02)$ & $0.64(0.04)$ & $0.74(0.02)$ & $0.82(0.05)$ & $0.82(0.17)$ & $0.69(0.13)$ & - \\
\hline & $\mathrm{g} / 100 \mathrm{~g}$ of fat & $0.39(1.60)$ & $0.41(0.98)$ & $0.46(0.50)$ & $0.53(0.90)$ & $0.64(0.53)$ & $0.67(1.14)$ & $0.50(3.50)$ & $0.09(2.77)$ & - \\
\hline Soyeurt et al. (2008) & $\mathrm{g} / \mathrm{dL}$ of milk & - & - & - & - & - & $0.90(0.05)$ & $0.84(0.17)$ & $0.85(0.10)$ & - \\
\hline \multirow{2}{*}{ Rutten et al. $(2009)^{1}$} & $\mathrm{~g} / \mathrm{dL}$ of milk & $0.91(0.1)$ & $0.96(0.2)$ & $0.94(0.5)$ & $0.92(0.1)$ & $0.85(0.3)$ & $0.94(0.03)$ & $0.94(0.1)$ & $0.82(0.7)$ & - \\
\hline & $\mathrm{g} / 100 \mathrm{~g}$ of fat & $0.55(0.0)$ & $0.73(0.3)$ & $0.73(0.6)$ & $0.75(0.2)$ & $0.68(0.3)$ & $0.73(0.3)$ & $0.71(0.0)$ & $0.51(1.2)$ & - \\
\hline De Marchi et al. (2011) & $\mathrm{g} / \mathrm{kg}$ of milk & - & - & $0.55(0.07)$ & $0.53(0.19)$ & $0.56(0.25)$ & $0.59(0.60)$ & $0.49(1.59)$ & $0.42(0.75)$ & $0.29(0.01)$ \\
\hline Ferrand et al. (2011) & $\begin{array}{l}\mathrm{g} / 100 \mathrm{~mL} \text { of } \\
\text { milk }\end{array}$ & $0.90(0.005)$ & $0.96(0.002)$ & $0.96(0.002)$ & $0.91(0.006)$ & $0.91(0.007)$ & $0.93(0.015)$ & $0.90(0.058)$ & $0.77(0.033)$ & - \\
\hline Soyeurt et al. (2011) & $\mathrm{g} / \mathrm{dL}$ of milk & $0.89(0.01)$ & $0.95(0.01)$ & $0.93(0.00)$ & $0.92(0.01)$ & $0.92(0.01)$ & $0.95(0.03)$ & $0.93(0.08)$ & $0.88(0.06)$ & - \\
\hline Maurice-Van Eijndhoven et al. (2013) & $\mathrm{g} / \mathrm{dL}$ of milk & $0.92(0.012)$ & $0.93(0.006)$ & $0.92(0.005)$ & $0.93(0.019)$ & $0.85(0.036)$ & $0.95(0.039)$ & $0.93(0.192)$ & $0.72(0.132)$ & - \\
\hline
\end{tabular}

${ }^{1}$ Prediction bias within parentheses.

Table 3. Unit of measurement, coefficient of determination, and prediction error (in parentheses) of validation procedures for mid-infrared spectroscopy (MIRS) prediction models of selected unsaturated FA

\begin{tabular}{|c|c|c|c|c|c|c|c|c|c|}
\hline \multirow[b]{2}{*}{ Reference } & \multirow[b]{2}{*}{ Unit } & \multicolumn{8}{|c|}{ Unsaturated FA } \\
\hline & & cis-9 C14:1 & cis-9 C16:1 & C18:1 & cis-9 C18:1 & trans-11 C18:1 & $\begin{array}{l}\text { cis-9,trans-11 } \\
\text { C18:2 }\end{array}$ & $\begin{array}{l}\text { cis-9, cis-12 } \\
\text { C18:2 }\end{array}$ & $\begin{array}{c}\text { cis- } 9, \text { cis }-12, \text { cis- } 15 \\
\text { C18:3 }\end{array}$ \\
\hline \multirow[t]{2}{*}{ Soyeurt et al. (2006) } & $\mathrm{g} / \mathrm{dL}$ of milk & $0.07(0.01)$ & $0.65(0.02)$ & $0.88(0.18)$ & - & - & $0.07(0.02)$ & $0.62(0.02)$ & $0.14(0.01)$ \\
\hline & $\mathrm{g} / 100 \mathrm{~g}$ of fat & $0.23(0.28)$ & $0.37(0.37)$ & $0.53(3.99)$ & - & - & $0.34(0.37)$ & $0.44(0.11)$ & $0.20(0.20)$ \\
\hline Soyeurt et al. (2008) & $\mathrm{g} / \mathrm{dL}$ of milk & $0.53(0.01)$ & $0.28(0.03)$ & - & - & - & - & - & - \\
\hline \multirow[t]{2}{*}{ Rutten et al. $(2009)^{1}$} & $\mathrm{~g} / \mathrm{dL}$ of milk & - & - & - & $0.92(0.3)$ & $0.63(0.4)$ & $0.58(1.0)$ & $0.36(0.9)$ & $0.45(3.3)$ \\
\hline & $\mathrm{g} / 100 \mathrm{~g}$ of fat & - & - & - & $0.84(0.5)$ & $0.57(0.6)$ & $0.56(1.1)$ & $0.28(0.6)$ & $0.38(2.8)$ \\
\hline De Marchi et al. (2011) & $\mathrm{g} / \mathrm{kg}$ of milk & $0.46(0.08)$ & $0.36(0.11)$ & - & $0.53(1.13)$ & $0.31(0.09)$ & $0.34(0.04)$ & - & - \\
\hline Ferrand et al. (2011) & $\mathrm{g} / 100 \mathrm{~mL}$ of milk & - & - & $0.91(0.037)$ & $0.91(0.036)$ & - & - & $0.65(0.004)$ & - \\
\hline Soyeurt et al. (2011) & $\mathrm{g} / \mathrm{dL}$ of milk & - & - & - & $0.95(0.06)$ & - & $0.63(0.01)$ & $0.71(0.01)$ & $0.60(0.01)$ \\
\hline Maurice-Van Eijndhoven et al. (2013) & $\mathrm{g} / \mathrm{dL}$ of milk & - & - & - & - & - & - & - & - \\
\hline
\end{tabular}


Ta

Table 4. Unit of measurement, coefficient of determination, and prediction error (in parentheses) of validation procedures for mid-infrared spectroscopy (MIRS) prediction models of selected groups of FA

\begin{tabular}{|c|c|c|c|c|c|c|c|c|}
\hline \multirow[b]{2}{*}{ Reference } & \multirow[b]{2}{*}{ Unit } & \multicolumn{7}{|c|}{ FA category $^{1}$} \\
\hline & & SFA & UFA & MUFA & PUFA & $\mathrm{SC}$ & $\mathrm{MC}$ & $\mathrm{LC}$ \\
\hline \multirow[t]{2}{*}{ Soyeurt et al. (2006) } & $\mathrm{g} / \mathrm{dL}$ of milk & $0.94(0.20)$ & $0.66(0.34)$ & $0.85(0.22)$ & $0.39(0.04)$ & - & - & - \\
\hline & $\mathrm{g} / 100 \mathrm{~g}$ of fat & $0.63(3.75)$ & $0.63(3.75)$ & $0.52(4.10)$ & $0.10(0.74)$ & - & - & - \\
\hline \multirow[t]{2}{*}{ Rutten et al. $(2009)^{2}$} & $\mathrm{~g} / \mathrm{dL}$ of milk & - & - & - & - & $0.95(0.0)$ & $0.97(0.0)$ & - \\
\hline & $\mathrm{g} / 100 \mathrm{~g}$ of fat & - & - & - & - & $0.82(0.3)$ & $0.77(0.1)$ & - \\
\hline De Marchi et al. (2011) & $\mathrm{g} / \mathrm{kg}$ of milk & $0.52(2.97)$ & $0.50(1.57)$ & $0.55(1.39)$ & $0.41(0.22)$ & - & $0.53(2.66)$ & $0.58(1.94)$ \\
\hline Ferrand et al. (2011) & $\mathrm{g} / 100 \mathrm{~mL}$ of milk & $0.98(0.038)$ & $0.91(0.043)$ & $0.92(0.040)$ & $0.38(0.008)$ & $0.97(0.008)$ & - & - \\
\hline Soyeurt et al. (2011) & $\mathrm{g} / \mathrm{dL}$ of milk & $0.99(0.08)$ & $0.97(0.07)$ & $0.97(0.06)$ & $0.81(0.02)$ & $0.95(0.02)$ & $0.96(0.12)$ & $0.96(0.12)$ \\
\hline Maurice-Van Eijndhoven et al. (2013) & $\mathrm{g} / \mathrm{dL}$ of milk & $0.99(0.078)$ & - & - & - & $0.95(0.028)$ & $0.96(0.190)$ & - \\
\hline
\end{tabular}

${ }^{1} \mathrm{UFA}=$ unsaturated $\mathrm{FA} ; \mathrm{SC}=$ short-chain $\mathrm{FA} ; \mathrm{MC}=$ medium-chain $\mathrm{FA} ; \mathrm{LC}=$ long-chain $\mathrm{FA}$.

${ }^{2}$ Prediction bias within parentheses.

(1)

.

Table 5. Number of calibration samples, dairy breed, reference method, range, spectra pretreatments, coefficient of determination $(1-\mathrm{VR}$, where VR = variance ratio), and SE of cross-validation $\left(\mathrm{SEC}_{\mathrm{CV}}\right.$ ) of validation procedures for mid-infrared prediction models of milk coagulation properties and milk acidity

\begin{tabular}{|c|c|c|c|c|c|c|c|c|}
\hline Reference & Trait $^{1}$ & $\mathrm{n}$ & Dairy breed & $\begin{array}{l}\text { Reference } \\
\text { method }^{2}\end{array}$ & Range & $\begin{array}{l}\text { Spectra } \\
\text { pretreatment }^{3}\end{array}$ & $1-\mathrm{VR}$ & $\mathrm{SEC}_{\mathrm{CV}}$ \\
\hline \multirow{2}{*}{ Dal Zotto et al. (2008) } & $\mathrm{RCT}(\min )$ & \multirow[t]{2}{*}{158} & \multirow{2}{*}{ Holstein-Friesian } & \multirow[t]{2}{*}{ CRM } & $9.20-25.8$ & $1 \mathrm{D}$ & 0.73 & 1.80 \\
\hline & $\mathrm{a}_{30}(\mathrm{~mm})$ & & & & $11.00-55.00$ & $1 \mathrm{D}$ & 0.45 & 5.49 \\
\hline \multirow{4}{*}{ De Marchi et al. (2009b) } & RCT (min) & \multirow[t]{4}{*}{1,064} & \multirow{4}{*}{ Brown Swiss } & \multirow[t]{4}{*}{$\mathrm{CRM}$} & $4.40-29.30$ & Untreated & 0.62 & 2.36 \\
\hline & $\mathrm{a}_{30}(\mathrm{~mm})$ & & & & $6.00-64.00$ & Untreated & 0.37 & 6.86 \\
\hline & & & & & $5.88-7.03$ & $1 \mathrm{D}, 1 \mathrm{D}+\mathrm{N}$ & 0.59 & 0.07 \\
\hline & TA $\left({ }^{\circ} \mathrm{SH} / 50 \mathrm{~mL}\right)$ & & & & $1.19-4.77$ & $1 \mathrm{D}$ & 0.66 & 0.25 \\
\hline \multirow[t]{4}{*}{ De Marchi et al. (2013) } & $\mathrm{RCT}(\min )$ & \multirow[t]{4}{*}{350} & \multirow[t]{4}{*}{ Holstein-Friesian } & \multirow[t]{4}{*}{ FOR } & $7.75-59.00$ & Untreated & 0.76 & 7.05 \\
\hline & $\mathrm{k}_{20}(\min )$ & & & & $2.00-28.45$ & Untreated & 0.72 & 3.54 \\
\hline & $\mathrm{a}_{30}(\mathrm{~mm})$ & & & & $0.36-51.30$ & Untreated & 0.70 & 7.68 \\
\hline & $\mathrm{a}_{60}(\mathrm{~mm})$ & & & & $0.76-40.96$ & Untreated & 0.40 & 7.26 \\
\hline
\end{tabular}

$\overline{{ }^{1} \mathrm{RCT}}=$ rennet coagulation time; $\mathrm{a}_{30}=$ curd firmness $30 \mathrm{~min}$ after rennet addition; $\mathrm{TA}=$ titratable acidity; ${ }^{\circ} \mathrm{SH}=$ Soxhlet-Henkel degree; $\mathrm{k}_{20}=$ curd-firming time; $\mathrm{a}_{60}=$ curd firmness $60 \mathrm{~min}$ after rennet addition.

${ }^{2} \mathrm{CRM}=$ computerized renneting meter (Polo Trade, Monselice, Italy); FOR = Formagraph (Foss Electric A/S, Hillerød, Denmark)

${ }^{3} 1 \mathrm{D}=$ first derivative; $1 \mathrm{D}+\mathrm{N}=$ first derivative and normalization. 
Milk clotting characteristics affect the efficiency of the cheese-making process. Milk with good aptitude to coagulate after rennet addition and to form a firm curd has been associated with increased cheese yield compared with milk that poorly reacts to the presence of the enzyme (Bynum and Olson, 1982; Riddell-Lawrence and Hicks, 1989). Common measures of MCP are rennet coagulation time (RCT; min), curd-firming time $\left(\mathbf{k}_{\mathbf{2 0}} ; \mathrm{min}\right)$, and curd firmness $\left(\mathbf{a}_{\mathbf{3 0}} ; \mathrm{mm}\right)$. Several studies reported across-breed (Auldist et al., 2002, 2004; De Marchi et al., 2007, 2008) and genetic variation of MCP, measured by reference mechanical methods (Ikonen et al., 2004; Tyrisevä et al., 2004; Cassandro et al., 2008) and predicted by MIRS (Cecchinato et al., 2009).

Prediction of MCP by MIRS has been investigated by Dal Zotto et al. (2008) and De Marchi et al. (2009b, 2013; Table 5). Dal Zotto et al. (2008) and De Marchi et al. (2009b) analyzed individual cow milk samples using the computerized renneting meter (Polo Trade, Monselice, Italy) as reference method, and they developed MIRS prediction models for RCT and $\mathrm{a}_{30}$, and De Marchi et al. (2013) developed MIRS prediction models for MCP (including $\mathrm{k}_{20}$ ) of samples that coagulated beyond $30 \mathrm{~min}$ from rennet addition, using the Formagraph (Foss Electric A/S, Hillerød, Denmark) as a reference instrument. The best calibration models were developed by De Marchi et al. (2013); according to Table 5, 1 - VR were $0.76,0.72$, and 0.76; the root mean square error of cross-validation (RMSEcv) were $7.05 \mathrm{~min}, 3.54 \mathrm{~min}$, and $7.68 \mathrm{~mm}$; and the RPD were $2.03,1.86$, and 1.80 for RCT, $\mathrm{k}_{20}$, and $\mathrm{a}_{30}$, respectively.

Results of De Marchi et al. (2013) on an extended testing time of analysis (60 min instead of the typical $30 \mathrm{~min}$ ) showed notably better prediction models for RCT and $\mathrm{a}_{30}$ than those reported by Dal Zotto et al. (2008) and De Marchi et al. (2009b; Table 5). Moreover, De Marchi et al. (2013) highlighted the potential of MIRS to predict $\mathrm{k}_{20}$, which is considered a trait of great practical importance in the dairy industry, as it suggests the optimal time at which curd-cutting should commence and, thus, it is related to product yield and quality (Bynum and Olson, 1982). Nevertheless, the comparison of papers in the literature is difficult because of different reference methods and the different types and concentrations of rennet used. The role of different methodologies in the assessment of MCP was investigated by Pretto et al. (2011), who proposed a method for the transformation of MCP obtained from various methodologies, and by Cipolat-Gotet et al. (2012), who compared MCP determined by Formagraph and by an optical instrument.

The prediction model for curd firmness $60 \mathrm{~min}$ after rennet addition was not completely satisfactory, as 1 -
VR, RMSEcv, and RPD for this trait were 0.40, 7.26 $\mathrm{mm}$, and 1.26, respectively (De Marchi et al., 2013). The low accuracy of prediction might be related to low accuracy of reference analysis for late-coagulating milk samples. This was previously reported by CipolatGotet et al. (2012), who found large variability for curd firmness measured 45 min after rennet addition.

Finally, in most studies MIRS prediction models were developed using untreated spectral data. This consisted with the results reported by De Marchi et al. (2009b) who investigated the effect of different spectra pretreatments for the prediction of MCP, showing better accuracies using untreated spectral data with respect to first- or second-derivative pretreatments.

Concerning milk acidity, 2 main measures could be identified: $\mathrm{pH}$ and titratable acidity (TA). Both traits are very important in cheese production. Titratable acidity is related to the aggregation rate of paracasein micelles, the reactivity of rennet, and the rate of syneresis; usually, milk with low values of TA (hypoacid milk) is considered unsuitable for cheese making (Formaggioni et al., 2001). The $\mathrm{pH}$ of milk affects enzymatic and aggregation reactions. De Marchi et al. (2009b) evaluated the potential of MIRS to predict TA and $\mathrm{pH}$ (Table 5); results were quite satisfactory, as 1 VR were 0.59 and 0.66 , and RMSEcv were 0.07 and 0.25 Soxhlet-Henkel degrees $\left({ }^{\circ} \mathrm{SH}\right) / 50 \mathrm{~mL}$ for $\mathrm{pH}$ and TA, respectively. Quite similar results were found by Colinet et al. (2010), who predicted TA with 1 - VR greater than 0.90 and RPD of 3.13 .

Overall, MIRS is a valid tool for predicting MCP and milk acidity of bovine milk and, thus, it might be adopted in payment systems to reward or penalize producers of milk, according to its clotting characteristics, as well as for breeding purposes (Tiezzi et al., 2013; Penasa et al., 2014).

\section{MILK PROTEIN COMPOSITION}

Milk proteins have gained interest in dairy organizations worldwide mainly for their role in cheese production. Several studies have dealt with the effects of milk protein polymorphisms, in particular those of casein, on MCP (Comin et al., 2008; Heck et al., 2009; Penasa et al., 2010) and cheese yield (Wedholm et al., 2006; Bonfatti et al., 2011). Furthermore, milk proteins are relevant for some aspects related to human nutrition, such as the release of peptides with biological function (Caroli et al., 2009). Lactoferrin is one of these proteins and it can be found in most biological fluids (e.g., colostrum, milk, and blood). Lactoferrin is important for immune system maintenance, as it has antibacterial, antifungal, and antiviral properties (Farnaud and Evans, 2003; Baker and Baker, 2005). 
Heritability estimates of individual milk proteins are moderate to high, suggesting wide opportunity to alter the composition in cow milk using breeding if individual measurements of milk protein fractions are available on a large scale (Lopez-Villalobos, 2012).

Mid-infrared prediction models for protein, casein, and casein fractions are shown in Table 6. Only De Marchi et al. (2009a), Bonfatti et al. (2011), and Rutten et al. (2011) developed prediction models for casein fractions, whereas Luginbühl (2002), Sørensen et al. (2003), and Etzion et al. (2004) reported predictions only for casein and protein contents. As in the case of FA composition, reference methods play a basic role in the development of prediction models for milk protein composition. Studies that dealt with the use of MIRS to predict protein and casein contents referred to the Kjeldahl analytical method (Sørensen et al., 2003), and they reported excellent $1-\mathrm{VR}$ and RMSEcv of 0.94 to 0.97 , and 0.08 to $0.05 \mathrm{~g} / 100 \mathrm{~g}$ of milk, respectively (Table 6). On the other hand, MIRS models for casein and whey fractions measured using capillary zone electrophoresis or reversed-phase HPLC as reference methods showed moderate predictive ability (De Marchi et al., 2009a; Bonfatti et al., 2011; Rutten et al., 2011). On average, casein fractions were better predicted when the reference method was HPLC than capillary zone electrophoresis. We can hypothesize that the accuracies of gold standard methods play a key role in the development of infrared prediction models. Moreover, in this specific case and as reviewed by Recio et al. (1997), HPLC methods showed better accuracies with respect to capillary zone electrophoresis in the determination of protein composition.

The best prediction models were described by Bonfatti et al. (2011), with $1-\mathrm{VR}$ of $0.66,0.49,0.53$, 0.63 , and 0.40 for $\alpha_{\mathrm{S}^{-}} \mathrm{CN}, \alpha_{\mathrm{S}^{2}} \mathrm{CN}, \beta-\mathrm{CN}, \kappa-\mathrm{CN}$, and $\gamma$-CN, respectively, whereas no satisfactory results were obtained by Rutten et al. (2011), who reported 1 - VR of 0.18 and 0.28 for $\alpha_{\mathrm{S}_{1}} \mathrm{CN}$ and $\kappa-\mathrm{CN}$, respectively. De Marchi et al. (2009a) showed slightly lower accuracies compared with Bonfatti et al. (2011), analyzing similar data and using the same reference methods. Bonfatti et al. (2011) tried to predict casein fractions changing the unit of measurement of the traits (percentage of protein or casein); results were not satisfactory compared with those obtained from traits expressed per unit of milk and this confirms previous findings for FA.

Regarding the total whey protein and whey protein fractions, very similar results were obtained by De Marchi et al. (2009a), Bonfatti et al. (2011), and Rutten et al. (2011), with $1-\mathrm{VR}$, on average, of 0.55 , 0.35 , and 0.55 for total whey protein, $\alpha-\mathrm{LA}$, and $\beta-\mathrm{LG}$, respectively (Table 7). As with casein fractions, MIRS predictions of whey fractions were better when traits were expressed per unit of milk. Concerning the spectra pretreatments, the scientific literature reported contradictory results; in fact, De Marchi et al. (2009a) and Rutten et al. (2011) used untreated spectral data, whereas Bonfatti et al. (2011) used several preprocessed spectra methods.

According to Table 7, 1 - VR values for predicted lactoferrin would be $0.66,0.73$, and 0.75 in Lopez-Villalobos et al. (2009), Soyeurt et al. (2012), and Soyeurt et al. (2007), respectively. The prediction models were developed using 2 gold standard methods: (1) a commercial ELISA kit in the case of Soyeurt et al. (2007, 2012) and (2) HPLC in the case of Lopez-Villalobos et al. (2009). The large number $(\mathrm{n}=2,499)$ and the origin (3 countries) of milk samples, combined with firstderivative pretreatments, were probably responsible for the better prediction of lactoferrin from Soyeurt et al. (2012) compared with the other studies.

In general, results of the reviewed studies indicate that MIRS cannot predict milk protein composition with high accuracy and, hence, the prediction models are not currently suitable for the dairy industry (e.g., milk payment system).

\section{COW HEALTH AND ENERGY STATUS}

Mid-infrared spectroscopy has been studied as potential tool to predict several milk traits related to cow health and robustness, which are closely related to cow fertility and production. This is the case for ketosis, a metabolic disorder that affects high-producing cows and causes a loss of production and infertility. Ketosis is related to the abnormal increase of acetone and BHBA in blood and milk, and the potential to predict the ketone bodies using MIRS has been tested by several authors. Hansen (1999) obtained 1 - VR and RMSEcr of 0.81 and $0.27 \mathrm{mM}$, respectively, for acetone content of bovine milk; these results were useful for screening purposes (healthy vs. potential ketotic cows). Heuer et al. (2001) studied the ability of MIRS to predict acetone content and found greater 1 - VR compared with Hansen (1999), a specific relationship between 1,370 and $1,239 \mathrm{~cm}^{-1}$ wavelengths and acetone prediction, and an advantage in the accuracy of prediction related to second-derivative spectra pretreatment. The results reported by Hansen (1999) and Heuer et al. (2001), which allowed the screening of cows with subclinical ketosis, were confirmed by the calibration models developed by de Roos et al. (2007). de Roos et al. (2007) investigated the potential of MIRS to predict acetone and BHBA concentrations on 1,080 bovine samples and reported RMSEcv of 0.184 and 0.064 $\mathrm{m} M$ for acetone and BHBA, respectively. The ability of MIRS to predict acetone and BHBA concentrations 
Table 6. Unit of measurement, coefficient of determination, and prediction error (in parentheses) of validation procedures for mid-infrared spectroscopy (MIRS) prediction models of total protein, total casein, and protein fractions

\begin{tabular}{|c|c|c|c|c|c|c|c|c|c|}
\hline \multirow[b]{2}{*}{ Reference } & \multirow{2}{*}{$\begin{array}{l}\text { Spectra } \\
\text { pretreatment }{ }^{1}\end{array}$} & \multirow[b]{2}{*}{ Unit } & \multicolumn{7}{|c|}{ Protein } \\
\hline & & & Protein & Casein & $\alpha_{\mathrm{S} 1}-\mathrm{CN}$ & $\alpha_{\mathrm{S}_{2}-} \mathrm{CN}$ & $\beta-\mathrm{CN}$ & $\kappa-\mathrm{CN}$ & $\gamma-\mathrm{CN}$ \\
\hline Luginbühl (2002) & - & $\mathrm{g} / 100 \mathrm{~g}$ of milk & - & $0.997(0.047)$ & - & - & - & - & - \\
\hline Sørensen et al. (2003) & - & $\%$ & - & $0.97(0.035)$ & - & - & - & - & - \\
\hline Etzion et al. (2004) & - & $\%$ & $0.94(0.08)$ & - & - & - & - & - & - \\
\hline De Marchi et al. (2009a) & Untreated & $\mathrm{g} / \mathrm{L}$ of milk & $0.58(3.11)$ & $0.58(2.76)$ & $0.50(1.07)$ & $0.35(0.58)$ & $0.33(1.77)$ & $0.44(0.68)$ & - \\
\hline \multirow[t]{3}{*}{ Bonfatti et al. (2011) } & SNV, De, MSC, 1D, 2D & $\mathrm{g} / \mathrm{L}$ of milk & $0.78(2.13)$ & $0.77(1.91)$ & $0.66(0.89)$ & $0.49(0.48)$ & $0.53(1.37)$ & $0.63(0.55)$ & $0.40(0.10)$ \\
\hline & & $\%$ protein & - & - & $0.23(1.95)$ & $0.17(1.08)$ & $0.13(2.42)$ & $0.36(1.44)$ & $0.08(1.00)$ \\
\hline & & $\%$ casein & - & - & $0.20(2.34)$ & $0.19(1.25)$ & $0.16(2.63)$ & $0.36(1.62)$ & $0.09(1.14)$ \\
\hline Rutten et al. (2011) & Untreated & $\mathrm{g} / 100 \mathrm{~g}$ of milk & - & $0.25(1.50)$ & $0.18(1.52)$ & $0.26(1.20)$ & $0.19(1.42)$ & $0.28(0.49)$ & - \\
\hline
\end{tabular}

${ }^{1} \mathrm{SNV}=$ standard normal variate; $\mathrm{De}=$ detrend; $\mathrm{MSC}=$ multiplicative scatter correction; $1 \mathrm{D}=$ first derivative; $2 \mathrm{D}=$ second derivative.

Table 7. Unit of measurement, coefficient of determination, and prediction error (in parentheses) of validation procedures for mid-infrared spectroscopy (MIRS) prediction models of whey protein and selected whey protein fractions

\begin{tabular}{|c|c|c|c|c|c|c|}
\hline \multirow[b]{2}{*}{ Reference } & \multirow[b]{2}{*}{$\begin{array}{l}\text { Spectra } \\
\text { pretreatment }^{1}\end{array}$} & \multirow[b]{2}{*}{ Unit } & \multicolumn{4}{|c|}{ Protein } \\
\hline & & & Whey protein & $\alpha-\mathrm{LA}$ & $\beta-\mathrm{LG}$ & Lactoferrin \\
\hline Soyeurt et al. (2007) & Untreated & $\mathrm{mg} / \mathrm{L}$ of milk & - & - & - & $0.75(103.93)$ \\
\hline De Marchi et al. (2009a) & Untreated & $\mathrm{g} / \mathrm{L}$ of milk & $0.53(0.51)$ & $0.29(0.19)$ & $0.55(0.43)$ & \\
\hline Lopez-Villalobos et al. (2009) & Untreated & $\mathrm{mg} / \mathrm{L}$ of milk & - & - & - & $0.81^{2}$ \\
\hline \multirow[t]{3}{*}{ Bonfatti et al. (2011) } & SNV, De, MSC, 1D, 2D & $\mathrm{g} / \mathrm{L}$ of milk & $0.61(0.45)$ & $0.31(0.18)$ & $0.64(0.37)$ & - \\
\hline & & $\%$ protein & - & $0.31(0.42)$ & $0.42(0.74)$ & - \\
\hline & & $\%$ whey protein & - & - & $0.36(3.02)$ & - \\
\hline Rutten et al. (2011) & Untreated & $\mathrm{g} / 100 \mathrm{~g}$ of milk & $0.53(0.84)$ & $0.20(0.29)$ & $0.56(0.79)$ & - \\
\hline Soyeurt et al. (2012) & Untreated, rep, 1D, 1D + rep, 2D, 2D + rep & $\mathrm{mg} / \mathrm{L}$ of milk & - & - & - & $0.72(50.55)$ \\
\hline
\end{tabular}

$\delta \quad{ }^{1} \mathrm{SNV}=$ standard normal variate; $\mathrm{De}=$ detrend; $\mathrm{MSC}=$ multiplicative scatter correction; $1 \mathrm{D}=$ first derivative; $2 \mathrm{D}=$ second derivative; rep $=$ repeatability file.

$\stackrel{\varphi}{\varphi} \quad{ }^{2}$ Concordance correlation coefficient calculated according to Lin (1989). 
was also demonstrated by van Knegsel et al. (2010), who reported that cow hyperketonemia could be better predicted using models developed for acetone and BHBA contents than using fat-to-protein ratio.

The negative energy balance, typical of dairy cows, especially in early lactation (Berry et al., 2006, 2009), is known to be related to animal health and fertility (Beam and Butler, 1999). Several studies estimated genetic association between negative energy balance and animal health (Collard et al., 2000; Veerkamp et al., 2000), and proposed energy balance predictors such as change in BCS, milk fat-to-protein ratio, and FA composition of milk (de Roos et al., 2007; Roche et al., 2009; Stoop et al., 2009).

McParland et al. (2011) investigated the feasibility of using the MIRS spectrum as an indicator of body energy status in Holstein cows; the authors found quite satisfactory accuracies for direct energy balance, with 1 - VR from 0.50 to 0.56. However, the prediction models were developed using data from a single herd and 2 diets that differed only for the level of concentrates offered, and this might have affected the variability of data. McParland et al. (2012) went on to evaluate the ability of MIRS to predict body energy status across the United Kingdom and Ireland in both confinement and grazing systems. The accuracies of prediction models were quite satisfactory, with square root of the coefficients of multiple determination from 0.47 to 0.69 , 0.51 to 0.56 , and 0.76 to 0.80 for direct energy balance, body energy content, and energy intake, respectively. Moreover, in the same study, McParland et al. (2012) highlighted the importance of limiting the error on the reference measurements to obtain a satisfactory equation. In conclusion, MIRS prediction models developed by McParland et al. (2011, 2012) provided useful information on the energy status of cows to dairy farmers; in fact, through routine recording of these traits, changes in the energy status of cows could be related to herd management practices or cow individual characteristics (e.g., genetic merit).

\section{MINERAL COMPOSITION OF MILK AND OTHER TRAITS}

Minerals in milk play a key role for human health and for some technological aspects (e.g., coagulation process). Recently, Caroli et al. (2011) reviewed the relationships between the intake of several milk and dairy products and bone health (e.g., osteoporosis), with particular emphasis to calcium and other macro- and micronutrients. Calcium associated with phosphorus influenced the ability of milk to coagulate and affected the final consistency of coagulum (Fossa et al., 1994; Mariani et al., 1996).
As for the previously reviewed traits, the opportunity to predict mineral composition using MIRS is desirable, as it allows rapid and large-scale data recording. Only Soyeurt et al. (2009) investigated the potential of MIRS to predict the calcium, phosphorus, magnesium, sodium, and potassium content of cow milk based on the inductively coupled plasma atomic emission spectrometry gold method. Results showed the ability of MIRS to predict calcium and phosphorus $(1-$ VR of 0.87 and 0.85 , respectively), reasonable accuracies for magnesium and sodium (coefficient of determination in cross-validation of 0.65 ), and unsatisfactory results for potassium. Moreover, Soyeurt et al. (2009) reported that inductively coupled plasma atomic emission spectrometry without mineralization was an inappropriate method to determine the sodium concentration in milk.

Recently, Toffanin and De Marchi (2013) investigated the effectiveness of MIRS to predict calcium and phosphorus, and the relations of these traits with MCP. Milk samples of about 200 Holstein-Friesian cows were collected and MIRS spectra and reference values obtained by the inductively coupled plasma atomic emission spectroscopy method were recorded. Statistical analysis using external and cross-validation procedures showed quite satisfactory results, with 1 - VR ranging from 0.50 to 0.60 and from 0.67 to 0.80 for calcium and phosphorus, respectively.

Mid-infrared spectroscopy has also been used to predict hydrochloride tetracycline concentration in milk (Sivakesava and Irudayaraj, 2002); those authors reported very high accuracy of prediction using a limited range of tetracycline concentration (4 to 2,000, 520 to 2,000 , and 4 to $520 \mathrm{ppb}$ ) and first-derivative spectra pretreatment. More recently, MIRS has been used to predict methane emission of dairy cows (Dehareng et al., 2012) on a limited number of animals fed 2 diets to induce large variation in methane emissions, measured using the sulfur hexafluoride method. Prediction models were developed using the average daily milk spectrum that was collected at 5 different times over $5 \mathrm{~d}$ from each diet to find the best relationship between methane emissions and spectra information. The best results were obtained for spectra collected for $1.5 \mathrm{~d}$ after methane determination, with 1 - VR of 0.79. Moreover, an interesting relationship between FA and methane emissions was confirmed. Dehareng et al. (2012) suggested the use of MIRS models for screening purposes; however, the application of MIRS to predict methane emission needs to be further studied.

\section{CONCLUSIONS AND PERSPECTIVES}

Mid-infrared spectroscopy is a fast, large-scale, and low-cost methodology for collecting phenotypes. 
Its potential to predict milk quality traits (e.g., FA composition, MCP, and mineral content) and other milk characteristics related to cow health and energy status has been demonstrated. In the near future, MIRS could be used for the prediction of other milk traits: (1) potassium, magnesium, and zinc content, which are important for transmitting nerve impulses, for mineral structure of bones, for wound healing, and healthy immune systems; (2) phospholipids and acidic glycolipids, which are important for infant development; (3) vitamins $\mathrm{A}$ and $\mathrm{B}$, which are important for healthy eyes and skin; (4) sensory features, which are important for the characterization of milk taste, beyond its nutritional value; (5) cheese yield; and (6) whey components, such as glutathione, $\alpha$-tocopherol, and vitamin $\mathrm{C}$.

Several studies on the effect of spectra pretreatment and type of software are needed. From this point of view, the effect of the use of mathematical pretreatments is not completely known, especially when prediction models are developed for a new trait for which the success of calibration models is related to several spectra peaks. Moreover, the potential of different statistical software packages should be investigated; in fact, no studies have been conducted to compare the performance of chemometric with general statistics software.

Efforts should be made to transfer prediction models for new phenotypes to MIRS instruments available in milk laboratories to allow routine data recording at the population level. To facilitate the implementation of MIRS models in field conditions, close collaboration with companies producing MIRS instruments is recommended.

Another crucial point for improving the use of MIRS is to favor the exchange of spectra databases among countries to develop across-country MIRS prediction models that take into account the biological variability of the studied traits in different environmental conditions. To do this, standardized reference methods within and across country are needed. As reviewed in this paper, large variability of reference methods used for MIRS calibration exists, and this does not facilitate the exchange and comparison of predicted phenotypes from different countries.

Finally, MIRS allows the recording of many new phenotypes that can be used for breeding purposes. The application of MIRS predictions in breeding programs depends upon the genetic correlation between the predicted and measured values. If the correlation and the genetic variance of MIRS phenotypes are sizable with reasonable accuracies, practical utility exists in the MIRS models.

\section{ACKNOWLEDGMENTS}

This research was supported by Regione Veneto with the project "CheeseBull", n. 2070868, Reg. CE 1698/2005, P.S.R. del Veneto - DGR 1354 del 03/08/2011. The authors gratefully acknowledge Una Geary (Teagasc, Moorepark, Ireland) for reading and correcting the manuscript, which has helped to improve this review.

\section{REFERENCES}

Aleandri, R., J. C. Schneider, and L. G. Buttazzoni. 1989. Evaluation of milk for cheese production based on milk characteristics and Formagraph measures. J. Dairy Sci. 72:1967-1975.

Auldist, M., C. Mullins, B. O'Brien, B. T. O'Kennedy, and T. Guinee. 2002. Effect of cow breed on milk coagulation properties. Milchwissenschaft 57:140-143.

Auldist, M. J., K. A. Johnston, N. J. White, W. P. Fitzsimons, and M. J. Boland. 2004. A comparison of the composition, coagulation characteristics and cheesemaking capacity of milk from Friesian and Jersey dairy cows. J. Dairy Res. 71:51-57.

Baker, E. N., and H. M. Baker. 2005. Molecular structure, binding properties and dynamics of lactoferrin. Cell. Mol. Life Sci. 62:2531-2539.

Balabin, R. M., and S. V. Smirnov. 2011. Melamine detection by midand near-infrared (MIR/NIR) spectroscopy: A quick and sensitive method for dairy products analysis including liquid milk, infant formula, and milk powder. Talanta 85:562-568.

Beam, S. W., and W. R. Butler. 1999. Effects of energy balance on follicular development and first ovulation in postpartum dairy cows. J. Reprod. Fertil. Suppl. 54:411-424.

Berry, D. P., A. R. Cromie, N. McHugh, M. Burke, T. Pabiou, J. MacCarthy, J. F. Kearney, F. Buckley, R. D. Evans, D. Purfield, J. M. Coyne, B. W. Wickham, J. J. Crowley, and S. McParland. 2012. New traits for dairy cattle breeding. In 38th International Committee for Animal Recording (ICAR) Meeting, Cork, Ireland. Accessed Feb. 20, 2013. http://www.icar.org/Cork_2012/ Manuscripts/Published/Berry.pdf.

Berry, D. P., M. O'Donovan, and P. Dillon. 2009. Potential to genetically alter intake and energy balance in grass fed dairy cows. Pages 219-224 in Breeding for Robustness in Cattle. EAAP Publ. No. 126. Wageningen Academic Publishers, Wageningen, the Netherlands.

Berry, D. P., R. F. Veerkamp, and P. Dillon. 2006. Phenotypic profiles for body weight, body condition score, energy intake, and energy balance across different parities and concentrate feeding levels. Livest. Sci. 104:1-12.

Bonfatti, V., G. Di Martino, and P. Carnier. 2011. Effectiveness of mid-infrared spectroscopy for the prediction of detailed protein composition and contents of protein genetic variants of individual milk of Simmental cows. J. Dairy Sci. 94:5776-5785.

Bowman, J. C. 1974. An Introduction to Animal Breeding. Edward Arnold Ltd., London, UK.

Bynum, D. G., and N. F. Olson. 1982. Influence of curd firmness at cutting on Cheddar cheese yield and recovery of milk constituents. J. Dairy Sci. 65:2281-2290.

Caroli, A. M., S. Chessa, and G. J. Erhardt. 2009. Invited review: Milk protein polymorphisms in cattle: Effect on animal breeding and human nutrition. J. Dairy Sci. 92:5335-5352.

Caroli, A., A. Poli, D. Ricotta, G. Banfi, and D. Cocchi. 2011. Invited review: Dairy intake and bone health: A viewpoint from the state of the art. J. Dairy Sci. 94:5249-5262.

Cassandro, M., A. Comin, M. Ojala, R. Dal Zotto, M. De Marchi, L. Gallo, P. Carnier, and G. Bittante. 2008. Genetic parameters of milk coagulation properties and their relationships with milk 
yield and quality traits in Italian Holstein cows. J. Dairy Sci. 91:371-376.

Cecchinato, A., M. De Marchi, L. Gallo, G. Bittante, and P. Carnier. 2009. Mid-infrared spectroscopy predictions as indicator traits in breeding programs for enhanced coagulation properties of milk. J. Dairy Sci. 92:5304-5313.

Chilliard, Y., A. Ferlay, and M. Doreau. 2001. Effect of different types of forages, animal fat or marine oils in cow's diet on milk fat secretion and composition, especially conjugated linoleic acid (CLA) and polyunsaturated fatty acids. Livest. Prod. Sci. 70:31-48.

Cipolat-Gotet, C., A. Cecchinato, M. De Marchi, M. Penasa, and G. Bittante. 2012. Comparison between mechanical and near-infrared methods for assessing coagulation properties of bovine milk. J. Dairy Sci. 95:6806-6819.

Colinet, F. G., H. Soyeurt, C. Anceau, A. Vanlierde, N. Keyen, P. Dardenne, N. Gengler, and M. Sindic. 2010. Potential estimation of titratable acidity in cow milk using mid-infrared spectrometry. In 37th International Committee for Animal Recording (ICAR) Meeting, Riga, Latvia. Accessed Jan. 16, 2013. http://www.icar. org/Documents/Riga_2010/ppt/Colinet.pdf.

Collard, B. L., J. C. M. Dekkers, D. Petitclerc, and L. R. Schaeffer. 2000. Relationships between energy balance and health traits of dairy cattle in early lactation. J. Dairy Sci. 83:2683-2690.

Comin, A., M. Cassandro, S. Chessa, M. Ojala, R. Dal Zotto, M. De Marchi, P. Carnier, L. Gallo, G. Pagnacco, and G. Bittante. 2008. Effects of composite $\beta$ - and $\kappa$-casein genotypes on milk coagulation, quality, and yield traits in Italian Holstein cows. J. Dairy Sci. 91:4022-4027.

Dal Zotto, R., M. De Marchi, A. Cecchinato, M. Penasa, M. Cassandro, P. Carnier, L. Gallo, and G. Bittante. 2008. Reproducibility and repeatability of measures of milk coagulation properties and predictive ability of mid-infrared reflectance spectroscopy. J. Dairy Sci. 91:4103-4112.

De Marchi, M., G. Bittante, R. Dal Zotto, C. Dalvit, and M. Cassandro. 2008. Effect of Holstein-Friesian and Brown Swiss breeds on quality of milk and cheese. J. Dairy Sci. 91:4092-4102.

De Marchi, M., V. Bonfatti, A. Cecchinato, G. Di Martino, and P. Carnier. 2009a. Prediction of protein composition of individual cow milk using mid-infrared spectroscopy. Ital. J. Anim. Sci. 8(Suppl. 2):399-401.

De Marchi, M., R. Dal Zotto, M. Cassandro, and G. Bittante. 2007. Milk coagulation ability of five dairy cattle breeds. J. Dairy Sci. 90:3986-3992.

De Marchi, M., C. C. Fagan, C. P. O'Donnell, A. Cecchinato, R. Dal Zotto, M. Cassandro, M. Penasa, and G. Bittante. 2009b. Prediction of coagulation properties, titratable acidity, and $\mathrm{pH}$ of bovine milk using mid-infrared spectroscopy. J. Dairy Sci. 92:423-432.

De Marchi, M., M. Penasa, A. Cecchinato, M. Mele, P. Secchiari, and G. Bittante. 2011. Effectiveness of mid-infrared spectroscopy to predict fatty acid composition of Brown Swiss bovine milk. Animal 5:1653-1658.

De Marchi, M., M. Penasa, F. Tiezzi, V. Toffanin, and M. Cassandro. 2012. Prediction of milk coagulation properties by Fourier transform mid-infrared spectroscopy (FTMIR) for genetic purposes, herd management and dairy profitability. In 38th International Committee for Animal Recording (ICAR) Meeting, Cork, Ireland. Accessed Nov. 10, 2012. http://www.icar.org/Cork_2012/ Manuscripts/Published/Cassandro.pdf.

De Marchi, M., V. Toffanin, M. Cassandro, and M. Penasa. 2013. Prediction of coagulating and noncoagulating milk samples using mid-infrared spectroscopy. J. Dairy Sci. 96:4707-4715.

de Roos, A. P. W., H. J. C. M. van den Bijgaart, J. Hørlyk, and G. de Jong. 2007. Screening for subclinical ketosis in dairy cattle by Fourier transform infrared spectrometry. J. Dairy Sci. 90:1761-1766.

Dehareng, F., C. Delfosse, E. Froidmont, H. Soyeurt, C. Martin, N. Gengler, A. Vanlierde, and P. Dardenne. 2012. Potential use of milk mid-infrared spectra to predict individual methane emission of dairy cows. Animal 6:1694-1701.

Etzion, Y., R. Linker, U. Cogan, and I. Shmulevich. 2004. Determination of protein concentration in raw milk by mid-infrared Fourier transform infrared/attenuated total reflectance spectroscopy. J. Dairy Sci. 87:2779-2788.

Farnaud, S., and R. W. Evans. 2003. Lactoferrin-A multifunctional protein with antimicrobial properties. Mol. Immunol. 40:395-405.

Ferrand, M., B. Huquet, S. Barbey, F. Barillet, F. Faucon, H. Larroque, O. Leray, J. M. Trommenschlager, and M. Brochard. 2011. Determination of fatty acid profile in cow's milk using mid-infrared spectrometry: Interest of applying a variable selection by genetic algorithms before a PLS regression. Chemom. Intell. Lab. Syst. 106:183-189.

Formaggioni, P., M. Malacarne, A. Summer, E. Fossa, and P. Mariani. 2001. Milk with abnormal acidity. VI. The role of phosphorus content and the rennet-coagulation properties of Italian Friesian herd milks. Annali della Facolta di Medicina Veterinaria, Universita di Parma 21:261-268.

Fossa, E., M. Pecorari, S. Sandri, F. Tosi, and P. Mariani. 1994. Il ruolo del contenuto in caseina del latte nella produzione del Parmigiano-Reggiano: Composizione chimica, caratteristiche di coagulazione e comportamento tecnologico-caseario del latte. Sci. Tecn. Latt. Cas. 45:519-535.

Fuentes-Pila, J., M. A. DeLorenzo, D. K. Beede, C. R. Staples, and J. B. Holter. 1996. Evaluation of equations based on animal factors to predict intake of lactating Holstein cows. J. Dairy Sci. 79:1562-1571.

German, J. B., R. A. Gibson, R. M. Krauss, P. Nestel, B. Lamarche, W. A. van Staveren, J. M. Steijns, L. C. P. G. M. de Groot, A. L. Lock, and F. Destaillats. 2009. A reappraisal of the impact of dairy foods and milk fat on cardiovascular disease risk. Eur. J. Nutr. 48:191-203.

Grummer, R. R. 1991. Effect of feed on the composition of milk fat. J. Dairy Sci. 74:3244-3257.

Haaland, D. M., and E. V. Thomas. 1988. Partial least-squares methods for spectral analyses. 1. Relation to other quantitative calibration methods and the extraction of qualitative information. Anal. Chem. 60:1193-1202.

Hansen, P. W. 1999. Screening of dairy cows for ketosis by use of infrared spectroscopy and multivariate calibration. J. Dairy Sci. 82:2005-2010

Heck, J. M. L., A. Schennink, H. J. F. van Valenberg, H. Bovenhuis, M. H. P. W. Visker, J. A. M. van Arendonk, and A. C. M. van Hooijdonk. 2009. Effects of milk protein variants on the protein composition of bovine milk. J. Dairy Sci. 92:1192-1202.

Heuer, C., H. J. Luinge, E. T. G. Lutz, Y. H. Schukken, J. H. van der Maas, H. Wilmink, and J. P. T. M. Noordhuizen. 2001. Determination of acetone in cow milk by Fourier transform infrared spectroscopy for the detection of subclinical ketosis. J. Dairy Sci. 84:575-582.

Hildrum, K. I., M. Martens, and H. Martens. 1983. Research on analysis of food quality. In Proc. International Symposium on Control of Food Quality and Food Analysis. Reading University, Reading, UK.

Houle, D., D. R. Govindaraju, and S. Omholt. 2010. Phenomics: The next challenge. Nat. Rev. Genet. 11:855-866.

Ikonen, T., S. Morri, A.-M. Tyrisevä, O. Ruottinen, and M. Ojala. 2004. Genetic and phenotypic correlations between milk coagulation properties, milk production traits, somatic cell count, casein content, and pH of milk. J. Dairy Sci. 87:458-467.

ISO-IDF (International Organization for Standardization-International Dairy Federation). 2001. Milk and milk products - Extraction methods for lipids and liposoluble compounds. ISO 14156-IDF 172. International Dairy Federation, Brussels, Belgium.

ISO-IDF (International Organization for Standardization-International Dairy Federation). 2002. Milk fat-Preparation of fatty acid methyl esters. ISO 15884-IDF 184. International Dairy Federation, Brussels, Belgium.

Karoui, R., A. M. Mouazen, E. Dufour, L. Pillonel, D. Picque, J. De Baerdemaeker, and J.-O. Bosset. 2006. Application of the MIR for the determination of some chemical parameters in European Emmental cheeses produced during summer. Eur. Food Res. Technol. 222:165-170. 
Lillehammer, M., T. H. E. Meuwissen, and A. K. Sonesson. 2011. A comparison of dairy cattle breeding designs that use genomic selection. J. Dairy Sci. 94:493-500.

Lin, L. I.-K. 1989. A concordance correlation coefficient to evaluate reproducibility. Biometrics 45:255-268.

Lopez-Villalobos, N. 2012. Analysing the genetic basis of milk production traits. CAB Reviews 7:1-18.

Lopez-Villalobos, N., S. R. Davis, E. M. Beattie, J. Melis, S. Berry, S. Holroyd, R. J. Spelman, and R. G. Snell. 2009. Breed effects for lactoferrin concentration determined by Fourier transform infrared spectroscopy. Proc. N.Z. Soc. Anim. Prod. 69:1-5.

Luginbühl, W. 2002. Evaluation of designed calibration samples for casein calibration in Fourier transform infrared analysis of milk. Lebensm. Wiss. Technol. 35:554-558.

MacGibbon, A. K. H., and W. D. McLennan. 1987. Hardness of New Zealand patted butter: Seasonal and regional variations. N.Z. J. Dairy Sci. Tech. 22:143-156.

Mariani, P., G. Zanzucchi, and A. Summer. 1996. Contenuto di fosfato di calcio colloidale e grado di "mineralizzazione" della caseina in campioni di latte di massa di allevamenti bovini di razza Frisona. L'Industria del Latte 32:3-16.

Martens, H., S. A. Jensen, and P. Geladi. 1983. Multivariate linearity transformations for near infrared reflectance spectroscopy. Pages 205-234 in Proc. Nordic Symp. Appl. Stat. O. H. J. Christie, ed. Stokkland Forlag, Stavanger, Norway.

Maurice-Van Eijndhoven, M. H. T., H. Soyeurt, F. Dehareng, and M. P. L. Calus. 2013. Validation of fatty acid predictions in milk using mid-infrared spectrometry across cattle breeds. Animal $7: 348-354$.

Mc Hugh, N., T. H. E. Meuwissen, A. R. Cromie, and A. K. Sonesson. 2011. Use of female information in dairy cattle genomic breeding programs. J. Dairy Sci. 94:4109-4118.

McParland, S., G. Banos, B. McCarthy, E. Lewis, M. P. Coffey, B. O'Neill, M. O'Donovan, E. Wall, and D. P. Berry. 2012. Validation of mid-infrared spectrometry in milk for predicting body energy status in Holstein-Friesian cows. J. Dairy Sci. 95:7225-7235.

McParland, S., G. Banos, E. Wall, M. P. Coffey, H. Soyeurt, R. F. Veerkamp, and D. P. Berry. 2011. The use of mid-infrared spectrometry to predict body energy status of Holstein cows. J. Dairy Sci. 94:3651-3661.

Mele, M., R. Dal Zotto, M. Cassandro, G. Conte, A. Serra, A. Buccioni, G. Bittante, and P. Secchiari. 2009. Genetic parameters for conjugated linoleic acid, selected milk fatty acids, and milk fatty acid unsaturation of Italian Holstein-Friesian cows. J. Dairy Sci. 92:392-400.

Mensink, R. P., and M. B. Katan. 1992. Effect of dietary fatty acids on serum lipids and lipoproteins: A meta-analysis of 27 trials. Arterioscler. Thromb. 12:911-919.

Næs, T., T. Isaksson, T. Fearn, and T. Davies. 2002. A User-Friendly Guide to Multivariate Calibration and Classification. NIR Publications, Chichester, UK.

OptiMIR. 2012. The drop reflecting the health of dairy farms. Accessed Dec. 15, 2012. http://www.optimir.eu/en/index.php.

Penasa, M., M. Cassandro, D. Pretto, M. De Marchi, A. Comin, S. Chessa, R. Dal Zotto, and G. Bittante. 2010. Short communication: Influence of composite casein genotypes on additive genetic variation of milk production traits and coagulation properties in Holstein-Friesian cows. J. Dairy Sci. 93:3346-3349.

Penasa, M., F. Tiezzi, A. Sturaro, M. Cassandro, and M. De Marchi. 2014. A comparison of the predicted coagulation characteristics and composition of milk from multi-breed herds of Holstein-Friesian, Brown Swiss and Simmental cows. Int. Dairy J. 35:6-10. http://dx.doi.org/10.1016/j.idairyj.2013.10.004.

Pretto, D., M. De Marchi, M. Penasa, and M. Cassandro. 2013. Effect of milk composition and coagulation traits on Grana Padano cheese yield under field conditions. J. Dairy Res. 80:1-5.

Pretto, D., T. Kaart, M. Vallas, I. Jõudu, M. Henno, L. Ancilotto, M. Cassandro, and E. Pärna. 2011. Relationships between milk coagulation property traits analyzed with different methodologies. J. Dairy Sci. 94:4336-4346.
Pryce, J. E., M. E. Goddard, H. W. Raadsma, and B. J. Hayes. 2010. Deterministic models of breeding scheme designs that incorporate genomic selection. J. Dairy Sci. 93:5455-5466.

Recio, I., L. Amigo, and R. López-Fandiño. 1997. Assessment of the quality of dairy products by capillary electrophoresis of milk proteins. J. Chromatogr. B Analyt. Technol. Biomed. Life Sci. 697:231-242.

Riddell-Lawrence, S., and C. L. Hicks. 1989. Effect of curd firmness on stirred curd cheese yield. J. Dairy Sci. 72:313-321.

Rinnan, A., L. Nørgaard, F. van den Berg, J. Thygesen, R. Bro, and S. Balling Engelsen. 2009. Data pre-processing. Chapter 2 in Infrared Spectroscopy for Food Quality Analysis and Control. Academic Press, London, UK.

Riovanto, R., M. De Marchi, M. Cassandro, and M. Penasa. 2012. Use of near infrared transmittance spectroscopy to predict fatty acid composition of chicken meat. Food Chem. 134:2459-2464.

RobustMilk. 2012. Innovative and practical breeding tools for improved dairy products from more robust dairy cattle. Accessed Dec. 15, 2012. http://www.robustmilk.eu/.

Roche, J. R., N. C. Friggens, J. K. Kay, M. W. Fisher, K. J. Stafford, and D. P. Berry. 2009. Invited review: Body condition score and its association with dairy cow productivity, health, and welfare. J. Dairy Sci. 92:5769-5801.

Rutten, M. J. M., H. Bovenhuis, J. M. L. Heck, and J. A. M. van Arendonk. 2011. Predicting bovine milk protein composition based on Fourier transform infrared spectra. J. Dairy Sci. 94:5683-5690.

Rutten, M. J. M., H. Bovenhuis, K. A. Hettinga, H. J. F. van Valenberg, and J. A. M. van Arendonk. 2009. Predicting bovine milk fat composition using infrared spectroscopy based on milk samples collected in winter and summer. J. Dairy Sci. 92:6202-6209.

Savitzky, A., and M. J. E. Golay. 1964. Smoothing and differentiation of data by simplified least squares procedures. Anal. Chem. $36: 1627-1639$.

Sivakesava, S., and J. Irudayaraj. 2002. Rapid determination of tetracycline in milk by FT-MIR and FT-NIR spectroscopy. J. Dairy Sci. 85:487-493.

Sørensen, L. K., M. Lund, and B. Juul. 2003. Accuracy of Fourier transform infrared spectrometry in determination of casein in dairy cows' milk. J. Dairy Res. 70:445-452.

Soyeurt, H., C. Bastin, F. G. Colinet, V. M.-R. Arnould, D. P. Berry, E. Wall, F. Dehareng, H. N. Nguyen, P. Dardenne, J. Schefers, J. Vandenplas, K. Weigel, M. Coffey, L. Théron, J. Detilleux, E. Reding, N. Gengler, and S. McParland. 2012. Mid-infrared prediction of lactoferrin content in bovine milk: Potential indicator of mastitis. Animal 6:1830-1838.

Soyeurt, H., D. Bruwier, J.-M. Romnee, N. Gengler, C. Bertozzi, D. Veselko, and P. Dardenne. 2009. Potential estimation of major mineral contents in cow milk using mid-infrared spectrometry. J. Dairy Sci. 92:2444-2454.

Soyeurt, H., F. G. Colinet, V. M.-R. Arnould, P. Dardenne, C. Bertozzi, R. Renaville, D. Portetelle, and N. Gengler. 2007. Genetic variability of lactoferrin content estimated by mid-infrared spectrometry in bovine milk. J. Dairy Sci. 90:4443-4450.

Soyeurt, H., P. Dardenne, F. Dehareng, G. Lognay, D. Veselko, M. Marlier, C. Bertozzi, P. Mayeres, and N. Gengler. 2006. Estimating fatty acid content in cow milk using mid-infrared spectrometry. J. Dairy Sci. 89:3690-3695.

Soyeurt, H., F. Dehareng, N. Gengler, S. McParland, E. Wall, D. P. Berry, M. Coffey, and P. Dardenne. 2011. Mid-infrared prediction of bovine milk fatty acids across multiple breeds, production systems, and countries. J. Dairy Sci. 94:1657-1667.

Soyeurt, H., F. Dehareng, P. Mayeres, C. Bertozzi, and N. Gengler. 2008. Variation of $\Delta^{9}$-desaturase activity in dairy cattle. J. Dairy Sci. 91:3211-3224.

Stone, M. 1974. Cross-validatory choice and assessment of statistical predictions. J. R. Stat. Soc., B 36:111-147.

Stoop, W. M., H. Bovenhuis, J. M. L. Heck, and J. A. M. van Arendonk. 2009. Effect of lactation stage and energy status on milk fat composition of Holstein-Friesian cows. J. Dairy Sci. 92:1469-1478. 
Stuart, B. 2004. Infrared Spectroscopy: Fundamentals and Applications. John Wiley \& Sons Ltd., Chichester, UK.

Tiezzi, F., D. Pretto, M. De Marchi, M. Penasa, and M. Cassandro. 2013. Heritability and repeatability of milk coagulation properties predicted by mid-infrared spectroscopy during routine data recording, and their relationships with milk yield and quality traits. Animal 7:1592-1599.

Toffanin, V., and M. De Marchi. 2013. Prediction of calcium, phosphorus and titratable acidity, and relationships with coagulation traits and chemical composition of bovine milk. Ital. J. Anim. Sci. 12(Suppl. 1):37. (Abstr.)

Tyrisevä, A.-M., T. Vahlsten, O. Ruottinen, and M. Ojala. 2004. Noncoagulation of milk in Finnish Ayrshire and Holstein-Friesian cows and effect of herds on milk coagulation ability. J. Dairy Sci. 87:3958-3966.

van der Drift, S. G. A., R. Jorritsma, J. T. Schonewille, H. M. Knijn, and J. A. Stegeman. 2012. Routine detection of hyperketonemia in dairy cows using Fourier transform infrared spectroscopy analysis of $\beta$-hydroxybutyrate and acetone in milk in combination with test-day information. J. Dairy Sci. 95:4886-4898.

van Knegsel, A. T. M., S. G. A. van der Drift, M. Horneman, A. P. W. de Roos, B. Kemp, and E. A. M. Graat. 2010. Short communication: Ketone body concentration in milk determined by Fourier transform infrared spectroscopy: Value for the detection of hyperketonemia in dairy cows. J. Dairy Sci. 93:3065-3069.
Veerkamp, R. F., J. J. Oldenbroek, H. J. Van Der Gaast, and J. H. J. Van Der Werf. 2000. Genetic correlation between days until start of luteal activity and milk yield, energy balance, and live weights. J. Dairy Sci. 83:577-583.

Wedholm, A., L. B. Larsen, H. Lindmark-Månsson, A. H. Karlsson, and A. Andrén. 2006. Effect of protein composition on the cheesemaking properties of milk from individual dairy cows. J. Dairy Sci. 89:3296-3305.

Williams, P. C. 1987. Implementation of near-infrared technology. Pages 143-167 in Near-Infrared Technology in the Agricultural and Food Industries. 2nd ed. P. C. Williams and K. Norris, ed. American Association of Cereal Chemists, St. Paul, MN.

Williams, P. C. 2001. Implementation of near-infrared technology. Page 143 in Near-Infrared Technology in the Agricultural and Food Industries. 2nd ed. P. C. Williams and K. Norris, ed. American Association of Cereal Chemists, St. Paul, MN.

Williams, P. C. 2003. Near-infrared technology getting the best out of light. Page 109 in A Short Course in the Practical Implementation of Near Infrared Spectroscopy for the User. 1.1 ed. PDK Projects Inc., Nanaimo, BC, Canada.

Williams, P. C., and K. Norris. 2001. Near-Infrared Technology in the Agricultural and Food Industries. 2nd ed. American Association of Cereal Chemists, St. Paul, MN. 